\title{
Effects of Different Dispositions of Resistance Exercises on Subjective Perception of Effort, Discomfort and Affectivity in Older Women
}

\section{Efeitos de Diferentes Disposições de Exercícios Resistidos Sobre Percepção Subjetiva de Esforço, Desconforto e Afetividade em Mulheres Idosas}

\author{
Alex Silva Ribeiro*a; Cristiane Afonso ${ }^{\mathrm{b}}$; Matheus Amarante do Nascimento $;$ Márcio Rogério de Oliveira \\ Denilson de Castro Teixeira ${ }^{\mathrm{d}}$
}

\author{
aUNOPAR, Stricto Sensu Graduate Program in Physical Exercise in Health Promotion, PR, Brazil. \\ bUnopar, Physical Education Course. PR, Brazil. \\ 'State University of Paraná, State College of Education, Sciences and Languages of Paranavaí. PR, Brazil. \\ ${ }^{\mathrm{d} S}$ State University of Londrina, Stricto Sensu Graduate Program in Physical Education. PR, Brazil. \\ *E-mail: alex-silvaribeiro@hotmail.com \\ Recebido em: 25/04/2019; Aprovado em: 18/06/2019
}

\begin{abstract}
The purpose of the study was to verify the effect of two dispositions of resistance exercises on rate of perceived of effort (RPE), discomfort and affectivity in older women. Twenty older women $(68.0 \pm 6.6$ years, $69.8 \pm 12.7 \mathrm{~kg}$, and $155.9 \pm 7.0 \mathrm{~cm})$ performed in a balanced and randomized design two experimental conditions, namely: a circuit (CIRC) fashion and another in a traditional (TRAD) fashion. In both conditions, six resistance exercises in the following order were performed: push press with kettlebell, swing with kettlebell, plantar flexion, squatting, ladder displacement and shoulder flexion with naval rope, with the same load and three sets of 15 repetitions/exercise. In the CIRC condition; the exercises were performed in stations, with no interval among them, and at the end of the last exercise, a three-minute interval was performed. For the TRAD condition the exercises were performed in consecutive sets, with intervals of 90 s between the sets and the exercises. After 15 min of the closure of each session, the RPE (OMNI), feeling (Hardy and Rejeski) and a discomfort scale were applied. There was no significant difference $(P>0.05)$ among the sessions for PSE $(\mathrm{TRAD}=6.0 \pm 1.2$ vs. CIRC $=6.1 \pm 0.9)$, feeling $(\mathrm{TRAD}=3.7 \pm 1.6 \mathrm{vs} . \mathrm{CIRC}=3.6 \pm 1.2)$ and discomfort $(\mathrm{TRAD}=5.2 \pm 1.4 \mathrm{vs}$. CIRC $=5.1 \pm 1.3)$. The results suggest that PSE, discomfort and affective response to resistance exercises are similar when performed in CIRC or TRAD in older women.
\end{abstract}

Keywords: Exercise. Aging. Physical exertion.

\section{Resumo}

O objetivo do estudo foi verificar o efeito de duas diferentes disposições de execução de exercícios resistidos sobre a percepção subjetiva

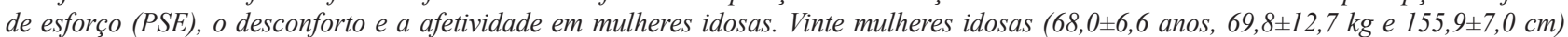
foram distribuídas de forma balanceada e aleatorizada para duas condições experimentais: disposição de circuito (CIRC) e disposição tradicional (TRAD). Em ambas as condições, seis exercícios resistidos foram executados na seguinte ordem: push press com kettlebell, swing com kettlebell, flexão plantar, agachamento, deslocamento em escada e flexão de ombros com corda naval, com mesma carga e três séries de 15 repetições/exercício. Na condição CIRC os exercícios foram executados em forma de estações, sem intervalo entre os exercícios e, ao final de cada série foi concedido intervalo de três minutos. Para condição TRAD os exercícios foram executados em séries consecutivas, com intervalos de 90 s entre os exercícios e as séries. Após 15 min do termino de cada sessão foram aplicadas as escalas de PSE (OMNI), sentimento (Hardy e Rejeski) e desconforto. Não ocorreram diferenças significativas $(P>0,05)$ entre as sessões para PSE $(T R A D=6,0 \pm 1,2$ vS CIRC $=$ $6,1 \pm 0,9$ ), sentimento (TRAD $=3,7 \pm 1,6$ vs $C I R C=3,6 \pm 1,2$ ) e desconforto (TRAD $=5,2 \pm 1,4$ vs CIRC $=5,1 \pm 1,3$ ). Os resultados sugerem que a PSE, o desconforto e a resposta afetiva aos exercícios resistidos são semelhantes quando realizados em CIRC ou TRAD em mulheres idosas.

Palavras-chave: Exercício Físico. Envelhecimento. Esforço Físico.

\section{Introduction}

Aging comes accompanied by a series of morphofunctional changes, being the reduction of the functional capacity and muscle mass important characteristics of this process ${ }^{1,2}$, which are associated with general health, autonomy and the longevity of the elderly ${ }^{3,4}$. Although the progressive decline of muscle fitness occurs in both women and men, elderly women have greater impairment of functional capacity and muscle mass that elderly men ${ }^{5-7}$.

In this sense, the regular practice of resistive exercise has been recommended, since they can promote important benefits to preserve the functional capacity and muscle mass
${ }^{8-10}$. Among the different forms of resistance exercises, the socalled functional training has been receiving prominence, in view of the fact that the literature indicates its efficiency to promote positive effects on the muscle, balance, the articular mobility and activities of daily life in elderly patients ${ }^{11}$.

The benefits associated with the practice of resistive exercise are dependent on appropriate adjustments of the components that make up the prescription of physical effort, including the load used, quantities of repetitions and series, recovery interval, weekly frequency, among others ${ }^{12}$. Additionally, the prescription may be delineated by traditional provision (TRAD) or in the form of circuit (CIRC) ${ }^{13}$. TRAD 
consists in performing multiple sets of the same exercise before starting the execution of the next ${ }^{13}$, while the CIRC consists of performing an initial series of each exercise, in a model of circuit, with the minimum interval among the exercises, until completing the amount of series planned for the physical exercise program ${ }^{14}$.

However, although both provisions provide positive adaptations to the health of the elderly, the physiological responses may be different. By characteristic, CIRC uses shorter intervals of recovery among the series and, in general, shorter intervals of recovery induce greater subjective perception of effort (PSE) ${ }^{15}$. Thus, the internal overload, the discomfort and sensations may present different responses between both fashions. Knowledge of different acute responses related to physical effort, the feeling of discomfort and feelings may be important for motivation and adherence of the practitioner.

The affective responses to physical exercise, such as pleasure and displeasure, should be considered to maximize adherence to physical exercise programs, since they can identify important correlation between affectivity to physical exercise and permanence in its practice ${ }^{16.17}$.

Considering the effectiveness of resistance exercises to promote positive adaptations on functionality ${ }^{18}$ and the absence of studies which check the various provisions of this type of physical exercise on internal demands effort, discomfort and feelings, the objective of this study was to verify the effect of two different provisions of resistive exercise on the PSE and affectivity in elderly women. The hypothesis is that the session is held in the form of CIRC shall induce greater physical effort and unpleasant sensations in comparison with the TRAD one. This hypothesis was based on shorter recovery intervals among the exercises and shorter duration of the session, two components inherent in the CIRC fashion.

\section{Material and Methods}

\subsection{Participants}

Twenty elderly women with prior experience ( $\geq 1$ year) in resistance exercises were selected by convenience to participate in the experiment. All participants completed a questionnaire to verify history of health and were included in the study, those who did not have a history of metabolic or musculoskeletal disorders that prevented the execution of physical exercise. The participants after receiving information about the purpose of the study and the procedures to which they would be subjected, signed the informed consent form. The research was approved by the Committee for Ethics in Research of Northern State University (opinion $n^{\circ} 2.956 .941$ ).

\subsection{Experimental design}

The participants performed three visits to the Center of Physical Exercise on alternate days, with a minimum interval of $48 \mathrm{~h}$. Anthropometric measures and individual interviews were conducted in the first visit. In the sequence, a randomized, balanced trial and in the form of cross-over was used for analysis of two experimental conditions: a session of resistive exercise with CIRC provision and one session of circuit resistance exercises with TRAD provision, performed in the second and third visit. The experimental design of the study is presented in Figure 1.

Figure 1 - Study experimental design.

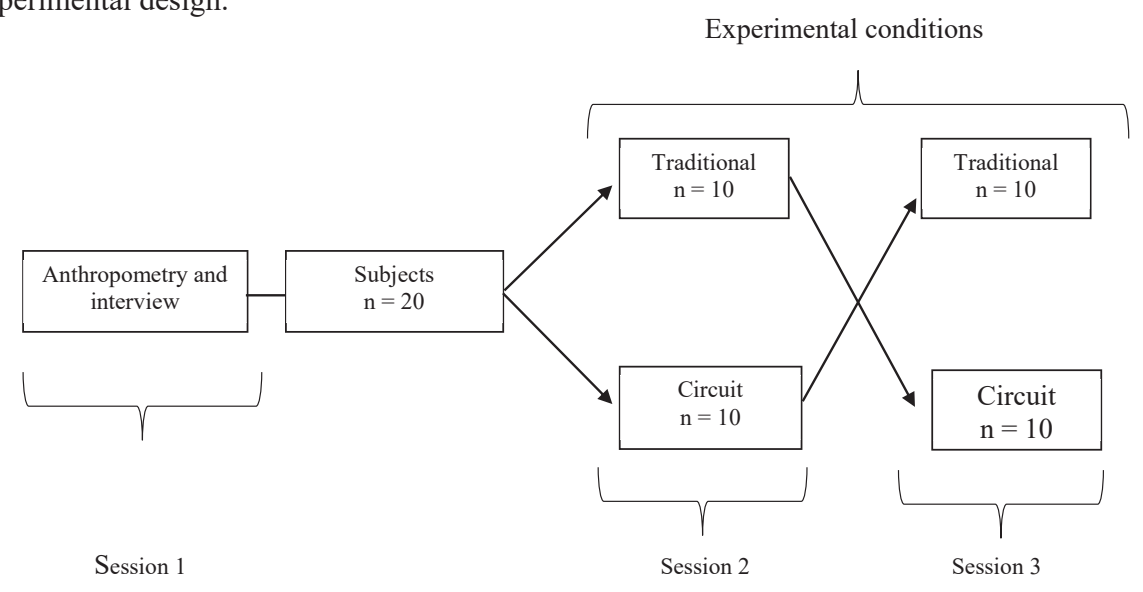

Source: The authors.

\subsection{Experimental conditions}

The participants performed in both experimental conditions (CIRC and TRAD) six resistance exercises in the following order: push press with kettlebell, swing with kettlebell, plantar flexion, squatting, ladder displacement and shoulder flexion with naval rope. In the CIRC condition the exercises were performed continuously, 15 repetitions/ exercise, with no interval among the exercises, and at the end of the last exercise, a three-minute recovery interval was performed. Each participant repeated the sequence of exercises for three times. The participants were accompanied in all resistance exercises by physical education professional. 
At the TRAD session the exercises were performed in the model of multiple series with intervals, which consisted in performing three sets of 15 repetitions/exercise, with recovery interval of 1-2 minutes between exercises and the series. The summarization on the experimental conditions is presented in Table 1.

Table 1 - Summarization of experimental conditions

\begin{tabular}{|c|c|c|c|}
\hline \multirow[t]{2}{*}{ Exercise } & \multirow[t]{2}{*}{ Load } & \multicolumn{2}{|c|}{ Condition } \\
\hline & & Traditional & Circuit \\
\hline Push press & Kettlebell 4kg & \multirow{6}{*}{$\begin{array}{l}3 \text { sets of each resistance } \\
\text { exercise } \\
\text { Interval between series: } 1-2 \\
\text { min } \\
15 \text { repetitions/exercise } \\
\text { Interval between exercises: } 1-2 \\
\text { min }\end{array}$} & \multirow{6}{*}{$\begin{array}{l}3 \text { sequences of six resistance } \\
\text { exercises } \\
\text { Interval between the sequences: } \\
3 \text { min } \\
15 \text { repetitions/exercise } \\
\text { Without interval between } \\
\text { resistance exercises of a same } \\
\text { sequence. }\end{array}$} \\
\hline Swing & Kettlebell 4kg & & \\
\hline Plantar flexion & Body weight & & \\
\hline Squat & Body weight & & \\
\hline Displacement in ladder & Body weight & & \\
\hline Shoulder push-ups & Naval rope $20 \mathrm{~kg}$ & & \\
\hline
\end{tabular}

Source: Research Data.

The participants were instructed to refrain from consumption of beverages and caffeinated foods $48 \mathrm{~h}$ before both the requests of implementation of resistance exercises and all visits were conducted in the morning.

\subsection{Subjective perception of effort, discomfort and pleasure/displeasure}

To determine the PSE the OMNI scale was used ${ }^{19}$. The subjective perception of discomfort (PSD) was determined from the scale of perception of discomfort ${ }^{20}$. To determine the perception of pleasure/displeasure (PPD) the scale of feeling affection proposed by Hardy and Rejesky ${ }^{21}$ was used, which is a bipolar scale of 11 points, ranging from +5 to -5 , with the zero score considered neutral, positive numbers $(+1$ to $+5)$ as feelings of pleasure and negative numbers ( -1 to -5$)$ as feelings of displeasure. All the scales were applied $15 \mathrm{~min}$ after the end of the sessions ${ }^{22.23}$.

\subsection{Statistical analysis}

The Shapiro-Wilk test was used for analysis of the data distribution. Confirmed the normality, test " $\mathrm{t}$ " test for paired samples was used for comparisons between sessions (TRAD vs CIRC). The magnitude of the differences was calculated by the size of the effect proposed by Cohen ${ }^{24}$ using the formula:

\section{MCIRC - MTRAD / DP}

Where MCIRC represents the average of the provision CIRC, MTRAD represents the average of the provision TRAD, and DP, the average of the standard deviations.

The effect size of $0.00-0.19$ was considered trivial, 0.20 0.49 was considered small, $0.50-0.79$ as moderate and $\geq 0.80$ as of great magnitude. For all statistical analyzes significance level of $P<0.05$ was accepted. Data were processed in statistical package SPSS, version 20.0.

\section{Results and Discussion}

The information regarding the general characteristics of the participants are presented in Table 2. The values of PSE, PSD, PPD and the duration of each session in accordance with the experimental condition are described in Table 3. There were no statistically significant differences among the sessions to PSE, PSD and PPD. The duration time of the session was higher for TRAD in comparison with CIRC. The size of the effect magnitude was trivial to PSE, PSD and PPD and of great magnitude for the duration of the session.

Table 2 - General characteristics of the sample $(n=20)$

\begin{tabular}{|l|c|c|c|c|}
\hline & Average & $\begin{array}{c}\text { Standard } \\
\text { Deviation }\end{array}$ & Minimum & Maximum \\
\hline Age (years) & 68.0 & 6.5 & 60 & 82 \\
\hline Body Mass $(\mathrm{kg})$ & 69.8 & 12.5 & 53 & 92 \\
\hline Height $(\mathrm{cm})$ & 155.9 & 6.9 & 144 & 171 \\
\hline BMI $\left(\mathrm{kg} / \mathrm{m}^{2}\right)$ & 28.7 & 4.8 & 21.8 & 38.1 \\
\hline
\end{tabular}

Note. BMI = body mass index.

Source: Research Data.

Table 3 - Variables in accordance with the experimental condition. Values expressed in mean and standard deviation

\begin{tabular}{|l|c|c|c|c|}
\hline & Traditional & Circuit & $\boldsymbol{P}$ & TE \\
\hline PSE & $6.0 \pm 1.2$ & $6.1 \pm 0.9$ & 0.68 & 0.02 \\
\hline PSD & $5.2 \pm 1.4$ & $5.1 \pm 1.3$ & 0.81 & -0.02 \\
\hline PPD & $3.7 \pm 1.6$ & $3.6 \pm 1.2$ & 0.91 & -0.02 \\
\hline $\begin{array}{l}\text { Session } \\
\text { length (min) }\end{array}$ & $50.3 \pm 2.9$ & $37.0 \pm 4.9$ & $<0.001$ & -0.85 \\
\hline
\end{tabular}

Note. PSE $=$ subjective perception of effort. PSD $=$ subjective perception of discomfort. PPD = perception of pleasure/displeasure. TE = size of the effect (less traditional circuit)

Source: Research Data.

The main finding of the present study was that sessions of resistive exercise performed in TRAD or CIRC fashions induce acute responses of perception of effort, discomfort and feelings of pleasure/displeasure similar in elderly women. The findings indicate that the internal effort was similar regardless of the provision used, since the perceived physical exertion was similar between the protocols used. Therefore, the initial hypothesis that CIRC induces greater internal effort was not confirmed. Some factors may explain, at least in part, the absence of differences between both provisions. For example, the two protocols used the same number of repetitions and load, and the literature indicates that these factors can affect 
the PSE.

Robertson et al. ${ }^{19}$ observed that for the same load $(65 \%$ 1RM), a greater quantity of repetitions can provide higher PSE. Still, some studies have observed that even with smaller loads, a greater quantity of repetitions performed until muscular failure induces the highest PSE. Pritchett et al. ${ }^{25}$ compared sessions performed to failure with moderate and high load (60\% and 90\% 1RM, respectively) and observed that PSE was higher for lower load $(8.8 \pm 0.8)$ when compared to the increased load $(6.3 \pm 1.2)$. Still, Shimano et al. ${ }^{26}$ also observed that in the squatting movement, more repetitions with smaller load (60\% 1RM) produced higher PSE compared to the smallest amount of repetitions and higher load $(80 \%$ and $90 \%$ of $1 \mathrm{RM})$. On the other hand, when the repetitions are not executed until the failure, studies indicate that higher loads induce higher $\mathrm{PSE}^{23,27-29}$.

Thus, as the loads and repetitions were listed among the provisions, the internal effort was also similar. As the number of repetitions was previously fixed in 15 repetitions per series, i.e., not ensuring that the effort was maximum, this effort may not have been sufficient to show differences between the protocols. Different results could be observed if the series had been carried out at the maximum, the series executed up to the momentary failure. However, in the present study it was chosen to compare two different similar provisions, leaving all other components associated with the resistance exercises that are not inherent in the two protocols.

Gauche et al. ${ }^{30}$, using a sample of hypertensive elderly women $(69.9 \pm 5.6$ years $)$ compared the PSE-session using seven conventional resistance exercises (leg press, rowing extensor chair, bench press, flexor table, cable fly and seated calf raise) in TRAD and CIRC fashion. In the TRAD session the participants performed three series of 12 repetitions/ exercise with one-minute intervals between exercises and the series. On CIRC condition three sequences were executed in the same exercises with 30 s interval between exercises and one minute between the sequences. The loads were similar in both conditions. The authors observed that PSE was significantly higher for the session TRAD $(5.2 \pm 1.3)$ compared to the CIRC session $(4.6 \pm 1.5)$. Although there was a trend $(P=0.07)$ for greater heart rate for CIRC $(97.6 \pm 17.0)$ in comparison with TRAD $(94.1 \pm 14.8)$. The conflicting results may be related to different methodological procedures, such as participants' age, once in the elderly the adjustments of some components of the resistive exercise do not seem to affect the PSE ${ }^{31.32}$.

Another important characteristis of this experiment is that, in addition to the perception of effort and discomfort, the study also verified the acute effect of loads in feelings of pleasure/ displeasure. The results showed no differences between the protocols used, in which both protocols also produced equal feelings of pleasure.

Although the internal overload has not differed statistically between the two considered provisions, the execution time of the session was lower for the condition CIRC, what, in practical terms, may be considered very important information, because the time spent for the execution of a physical exercise program is one of the barriers commonly cited by aged practitioners ${ }^{33}$ and, therefore, based on this result, the circuit condition can be a more attractive strategy.

The present study has some limitations. The findings should not be extrapolated for different populations, different loads and quantities of repetitions. It is worth remembering that the elderly women who participated in this experiment were accustomed to the routine of resistive exercise, thus different results can be observed in beginners. Absence of more direct measures of internal effort is also a limitation to be considered in the study. The results are acute, therefore, the possibility cannot be ruled out that the tolerance of the two provisions of the execution of the resistance exercises can be changed over time due to repeated exposure.

\section{Conclusion}

The results reported suggest that the effort and the discomfort perceived of the session, as well as affective response to resistance exercises were similar when executed $=$ on traditional provision or in circuit in elderly women. From the practical point of view, these findings indicate that the internal efforts and the affective response to both provisions may be used and may vary according to individual preference and availability for physical exercise.-

\section{References}

1. Brady AO, Straight CR, Evans EM. Body composition, muscle capacity, and physical function in older adults: an integrated conceptual model. J Aging Phys Act 2014;22(3):441-52. doi: 10.1123/japa.2013-0009

2. Clark BC, Manini TM. Functional consequences of sarcopenia and dynapenia in the elderly. Curr Opin Clin Nutr Metab Care 2010;13(3):271-6. doi: 10.1097/MCO.0b013e328337819e

3. Srikanthan P, Karlamangla AS. Muscle mass index as a predictor of longevity in older adults. Am J Med 2014;127(6):547-53. doi: 10.1016/j.amjmed.2014.02.007

4. Ruiz JR, Sui X, Lobelo F, Morrow JR, Jr., Jackson AW, Sjostrom M, et al. Association between muscular strength and mortality in men: prospective cohort study. BMJ 2008;337:a439. doi: 10.1136/bmj.a439

5. Janssen I, Heymsfield SB, Wang ZM, Ross R. Skeletal muscle mass and distribution in 468 men and women aged 18-88 yr. J Appl Physiol (1985) 2000;89(1):81-8.

6. Delmonico MJ, Harris TB, Visser M, Park SW, Conroy MB, Velasquez-Mieyer $P$, et al. Longitudinal study of muscle strength, quality, and adipose tissue infiltration. Am J Clin Nutr 2009;90(6):1579-85. doi: 10.3945/ajen.2009.28047

7. Hughes VA, Frontera WR, Wood M, Evans WJ, Dallal GE, Roubenoff R, et al. Longitudinal muscle strength changes in older adults: influence of muscle mass, physical activity, and health. J Gerontol A Biol Sci Med Sci 2001;56(5):B209-17.

8. Cadore EL, Rodriguez-Manas L, Sinclair A, Izquierdo M. Effects of different exercise interventions on risk of falls, gait ability, and balance in physically frail older adults: a systematic review. Rejuvenation Res 2013;16(2):105-14. doi: 
10.1089/rej.2012.1397

9. Latham NK, Bennett DA, Stretton CM, Anderson CS. Systematic review of progressive resistance strength training in older adults. J Gerontol A Biol Sci Med Sci 2004;59(1):4861.

10. Lopez P, Pinto RS, Radaelli R, Rech A, Grazioli R, Izquierdo $\mathrm{M}$, et al. Benefits of resistance training in physically frail elderly: a systematic review. Aging Clin Exp Res 2017. doi: $10.1007 / \mathrm{s} 40520-017-0863-\mathrm{Z}$

11. Liu C, Shiroy DM, Jones LY, Clark DO. Systematic review of functional training on muscle strength, physical functioning, and activities of daily living in older adults. Euro Rev Aging Phys Activity 2014;11(2):95-106. doi: 10.1007/s11556-0140144-1

12. Cadore EL, Pinto RS, Bottaro M, Izquierdo M. Strength and endurance training prescription in healthy and frail elderly. Aging Dis 2014;5(3):183-95. doi: 10.14336/ AD.2014.0500183

13. ACSM. American College of Sports Medicine position stand. Progression models in resistance training for healthy adults. Med Sci Sports Exerc 2009;41(3):687-708. doi: 10.1249/ MSS.0b013e3181915670

14. Romero-Arenas S, Martinez-Pascual M, Alcaraz PE. Impact of resistance circuit training on neuromuscular, cardiorespiratory and body composition adaptations in the elderly. Aging Dis 2013;4(5):256-63. doi: 10.14336/ AD.2013.0400256

15. Farah BQ, Lima AH, Lins-Filho OL, Souza DJ, Silva GQ, Robertson RJ, et al. Effects of rest interval length on rating of perceived exertion during a multiple-set resistance exercise. Percept Mot Skills 2012;115(1):273-82. doi: 10.2466/06.05.25.PMS.115.4.273-282

16. Ekkekakis P. Let them roam free? Physiological and psychological evidence for the potential of selfselected exercise intensity in public health. Sports Med 2009;39(10):857-88. doi: 10.2165/11315210-00000000000000

17. Williams DM, Dunsiger S, Ciccolo JT, Lewis BA, Albrecht $\mathrm{AE}$, Marcus BH. Acute affective response to a moderateintensity exercise stimulus predicts physical activity participation 6 and 12 months Later. Psychol Sport Exerc 2008;9(3):231-45. doi: 10.1016/j.psychsport.2007.04.002

18. Teixeira CVLS, Evangelista AL, Pereira CA, Da SilvaGrigoletto ME. Short roundtable RBCM: treinamento funcional. Rev Bras Cienc Mov 2016;24(1):200-6.

19. Robertson RJ, Goss FL, Rutkowski J, Lenz B, Dixon $\mathrm{C}$, Timmer $\mathrm{J}$, et al. Concurrent validation of the OMNI perceived exertion scale for resistance exercise. Med Sci Sports Exerc 2003;35(2):333-41. doi: 10.1249/01. MSS.0000048831.15016.2A

20. Steele J, Fisher J, McKinnon S, McKinnon P. Differentiation between perceived effort and discomfort during resistance training in older adults:Reliability of trainee ratings of effort and discomfort,and reliability and validity of trainer ratings of trainee effort. Journal of Trainology 2016;6(1):1-8. doi: 10.17338/trainology.6.1 1

21. Hardy CJ, Rejeski WJ. Not what, but how one feels: the measurement of affect during exercise. Journal of Sport and Exercise Psychology 1989;11(3):304-17. doi: 10.1123/ jsep.11.3.304

22. Scott BR, Duthie GM, Thornton HR, Dascombe BJ. Training monitoring for resistance exercise: theory and applications. Sports Med 2016;46(5):687-98. doi: 10.1007/s40279-0150454-0

23. Hiscock DJ, Dawson B, Peeling P. Perceived exertion responses to changing resistance training programming variables. J Strength Cond Res 2015;29(6):1564-9. doi: $10.1519 /$ JSC. 0000000000000775

24. Cohen J. A power primer. Psychol Bull 1992;112(1):155-9.

25. Pritchett RC, Green JM, Wickwire PJ, Pritchett KL, Kovacs PS. Acute and session RPE responses during resistance training: bouts to failure at $60 \%$ and $90 \%$ of $1 \mathrm{RM}$. South African J Sports Med 2009;21(1):23-6.

26. Shimano T, Kraemer WJ, Spiering BA, Volek JS, Hatfield DL, Silvestre R, et al. Relationship between the number of repetitions and selected percentages of one repetition maximum in free weight exercises in trained and untrained men. J Strength Cond Res 2006;20(4):819-23. doi: 10.1519/ R-18195.1

27. Day ML, McGuigan MR, Brice G, Foster C. Monitoring exercise intensity during resistance training using the session RPE scale. J Strength Cond Res 2004;18(2):353-8. doi: 10.1519/R-13113.1

28. Gearhart RF, Jr., Goss FL, Lagally KM, Jakicic JM, Gallagher $\mathrm{J}$, Gallagher KI, et al. Ratings of perceived exertion in active muscle during high-intensity and low-intensity resistance exercise. J Strength Cond Res 2002;16(1):87-91.

29. Sweet TW, Foster C, McGuigan MR, Brice G. Quantitation of resistance training using the session rating of perceived exertion method. J Strength Cond Res 2004;18(4):796-802. doi: $10.1519 / 14153.1$

30. Gauche R, Ferreira-Junior JB, Gadelha AB, Neri SG, Bottaro M, Vianna LC, et al. Session perceived exertion following traditional and circuit resistance exercise methods in older hypertensive women. Percept Mot Skills 2016. doi: $10.1177 / 0031512516680436$

31. Ferreira SS, Krinski K, Alves RC, Benites ML, Redkva PE, Elsangedy HM, et al. The Use of session RPE to monitor the intensity of weight training in older women: acute responses to eccentric, concentric, and dynamic exercises. J Aging Res 2014;2014:749317. doi: 10.1155/2014/749317

32. Conlon JA, Haff GG, Tufano JJ, Newton RU. Application of session rating of perceived exertion among different models of resistance training in older adults. J Strength Cond Res 2015;29(12):3439-46. doi: 10.1519/JSC.0000000000001200

33. Picorelli AM, Pereira DS, Felicio DC, Dos Anjos DM, Pereira DA, Dias RC, et al. Adherence of older women with strength training and aerobic exercise. Clin Interv Aging 2014;9:32331. doi: 10.2147/CIA.S54644 